THE GREEK REVOLUTION 


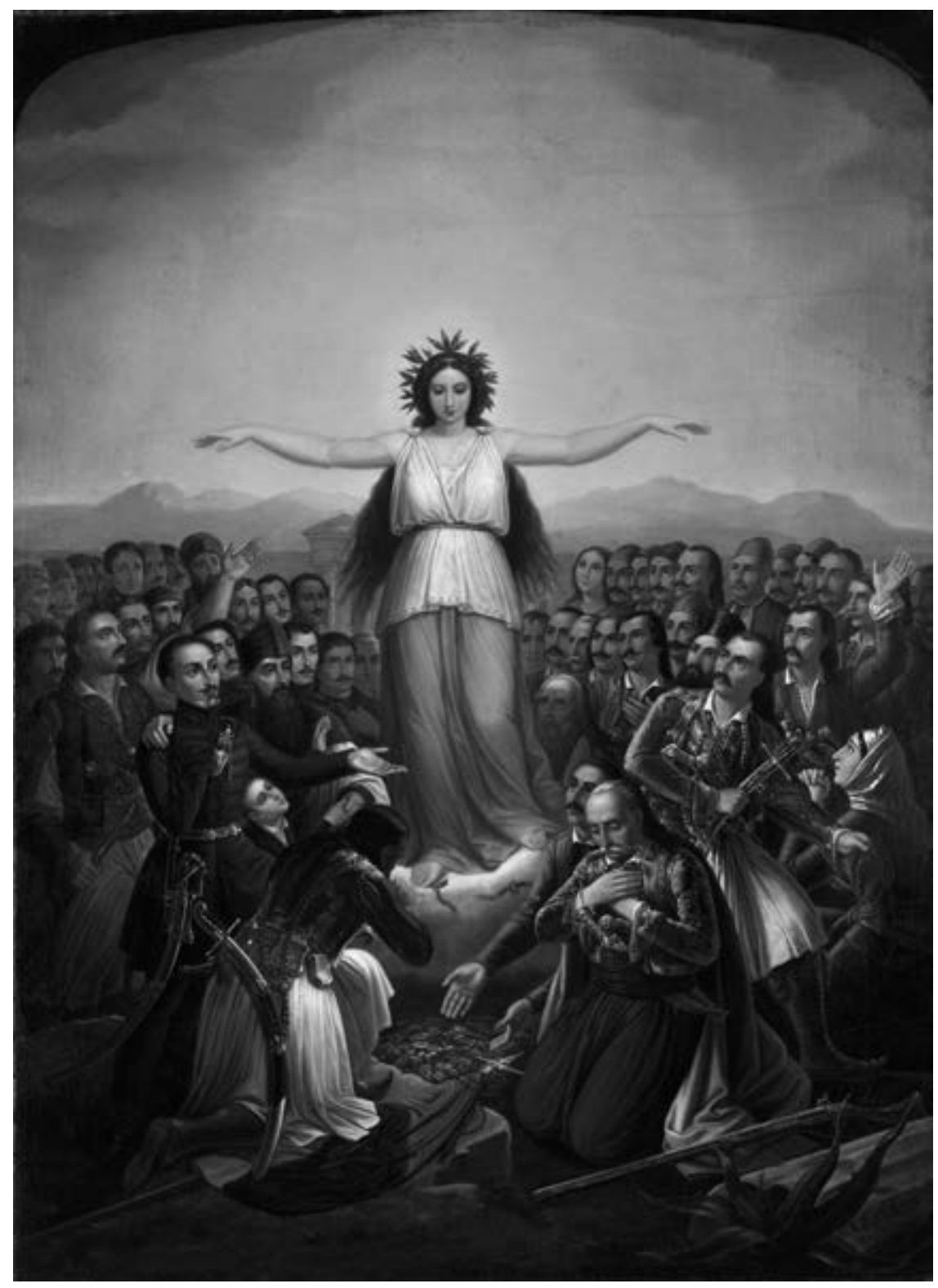

Theodoros Vryzakis, Hellas in Gratitude, 1858. National Gallery-Al. Soutzos Museum, Athens. 

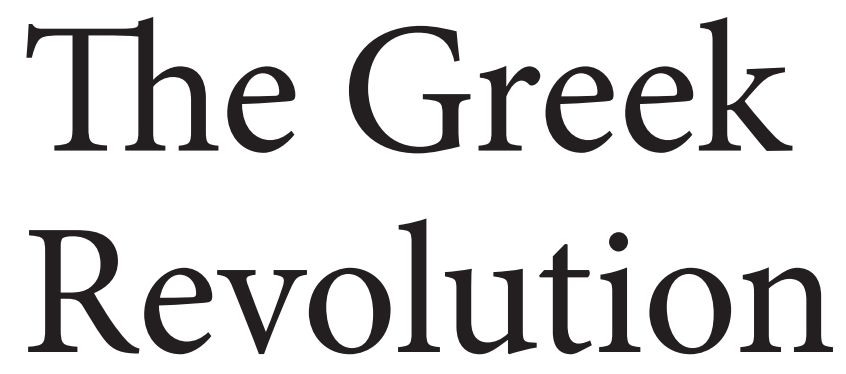

\section{A CRITICAL DICTIONARY}

Edited by

Paschalis M. Kitromilides

\& Constantinos Tsoukalas

THE BELKNAP PRESS OF

HARVARD UNIVERSITY PRESS

Cambridge, Massachusetts

London, England 2021 
Copyright (C) 2021 by Paschalis M. Kitromilides and Constantinos Tsoukalas All rights reserved

Printed in the United States of America

First printing

Jacket design: Annamarie McMahon Why

Jacket art: Peter von Hess, A Greek Commander and His Pallikars in the Fight, 1829. Oil on canvas, after the lithograph by Karl Krazeisen. Thanassis and Marina Martinos Collection, Athens.

9780674259317 (EPUB)

$9780674259324(\mathrm{PDF})$

Translations from Greek by Alexandra Douma.

Frontispiece: Hellas in Gratitude, Theodoros Vryzakis, 1858. National Gallery, Athens.

The Library of Congress has cataloged the printed edition as follows:

Names: Kitromilides, Paschalis, editor. | Tsoukalas, Kōnstantinos, 1937- editor.

Title: The Greek revolution : a critical dictionary / edited by Paschalis M. Kitromilides and Constantinos Tsoukalas.

Description: Cambridge, Massachusetts : The Belknap Press of Harvard University Press, 2021. | Includes bibliographical references and index.

Identifiers: LCCN 2020040853 | ISBN 9780674987432 (cloth)

Subjects: LCSH: Philhellenism. | Greece-History-War of Independence, 1821-1829.

Classification: LCC DF805 .G738 $2021 \mid$ DDC 949.5 / o603-dc23

LC record available at https://lccn.loc.gov/2020040853 
In honor of the generations of scholars who, across two hundred years, have devoted their intellectual labor to the study of the Greek Revolution 
